\title{
Three New Species of the Family Eosentomidae (Protura) from the Nasu Imperial Villa, Central Japan
}

\author{
Osami Nakamura \\ Omaeda 2507-9, Fukaya-shi, Saitama 369-1246, Japan \\ E-mail:osami@nakamura.email.ne.jp \\ (Received 8 September 2020; Accepted 25 February 2021) \\ http://zoobank.org/A1208587-E61D-47C0-809D-54172EA24DD9
}

\begin{abstract}
Three new proturan species, Eosentomon villare sp. nov., Pseudanisentomon nasuense sp. nov., and P. villaticum sp. nov., collected from the Nasu Imperial Villa, Tochigi Prefecture, central Japan are described. Eosentomon villare sp. nov. is characterized by the absence of foretarsal sensillum $b^{\prime} 1$, a long empodium on the hind tarsus, four pairs of anterior setae on abdominal tergite VII $(A 1,2,4$, and 5), two anterior and seven posterior setae on sternite VIII, and six setae on sternites IX-X. Both $P$. nasuense sp. nov. and P. villaticum sp. nov. also lack foretarsal sensillum $b^{\prime} 1$. Pseudanisentomon nasuense sp. nov. has long empodia on the middle and hind tarsus and five pairs of anterior setae on abdominal tergite IV. Pseudanisentomon villaticum sp. nov. is distinguished from its congeners by the number of anterior setae on abdominal tergite VII (three pairs: $A 2,4$, and 5), the absence of foretarsal sensillum $c^{\prime}$ and seta $x$, and rudimentary setae 1 and 2 on tergite XI. In addition to descriptions of these new species, an updated key to species of Pseudanisentomon Zhang and Yin, 1984 is provided.
\end{abstract}

Key Words: Eosentomon, Pseudanisentomon, key, chaetotaxy, taxonomy.

\section{Introduction}

The Nasu Imperial Villa (area: ca. $660 \mathrm{ha}$ ) is located at the southeastern foot of Mt. Chausu-dake in Nasu-machi, Tochigi Prefecture, central Japan. Part of the area was once used as pastureland; however, the grassland landscape had previously been lost due to the cessation of grazing and the establishment of forest. In December 2011, the Garden Division of the Imperial Household Agency cut down trees to re-grass the area. In conjunction with re-grassing, soil fauna surveys were conducted from 2011 to 2015 in an initiative by the Tochigi Prefectural Museum. During these surveys, 2914 proturan specimens were collected including 19 determined species belonging to nine genera in three families. Undetermined eosentomid specimens also were obtained (Nakamura 2019); these were closely examined and three species new to science were identified. One new species of Eosentomon Berlese, 1908 and two new species of Pseudanisentomon Zhang and Yin, 1984 are described below. In addition, an updated key to the species of Pseudanisentomon is provided.

\section{Materials and Methods}

Substrate was collected from four sites of secondary forest dominated by Quercus crispula Blume and Pinus densiflora Siebold and Zucc. in the Nasu Imperial Villa. Protura were extracted from litter and soils using Tullgren funnels and then preserved in $95 \%$ ethanol. Subsequently, specimens were individually mounted in polyvinyl lactophenol medium. They were manipulated into position with a pin embedded in a wooden stick and then covered with a coverslip. These slides were dried for four days in an oven at $60^{\circ} \mathrm{C}$. Morphological characters were observed using differential interference microscopy (Olympus BHS-N) and specimens were drawn with the aid of a drawing tube (Olympus BH2-DA).

Most terms and designations used here are after Tuxen (1964) and Imadaté (1974). However, descriptions of some characteristics, e.g., chaetotaxy of the head and hind tarsus, and the structure of some elements of the mouthparts, are after Bernard (1990).

In the following descriptions, the holotype measurement is given first followed by the range of paratype measurements in parentheses. Holotypes and some of the paratypes are deposited in the collection of the National Museum of Nature and Science (NSMT), and some of the paratypes are in the collections of Tochigi Prefectural Museum (TPM) and Saitama Museum of Natural History (SMNH).

\section{Taxonomy}

Family Eosentomidae Berlese, 1909

Genus Eosentomon Berlese, 1908 Eosentomon villare sp. nov.

(Figs 1, 2; Table 1)

Eosentomon sp. NIV: Nakamura 2019: 18.

Diagnosis. Labral setae present; cephalic anterior additional setae absent; foretarsal sensilla $b^{\prime} 1$ and $c^{\prime}$ absent; long empodium on hind tarsus; abdominal tergites V-VII with four pairs of anterior setae $(A 1,2,4,5), P 1 a$ on VII short at 

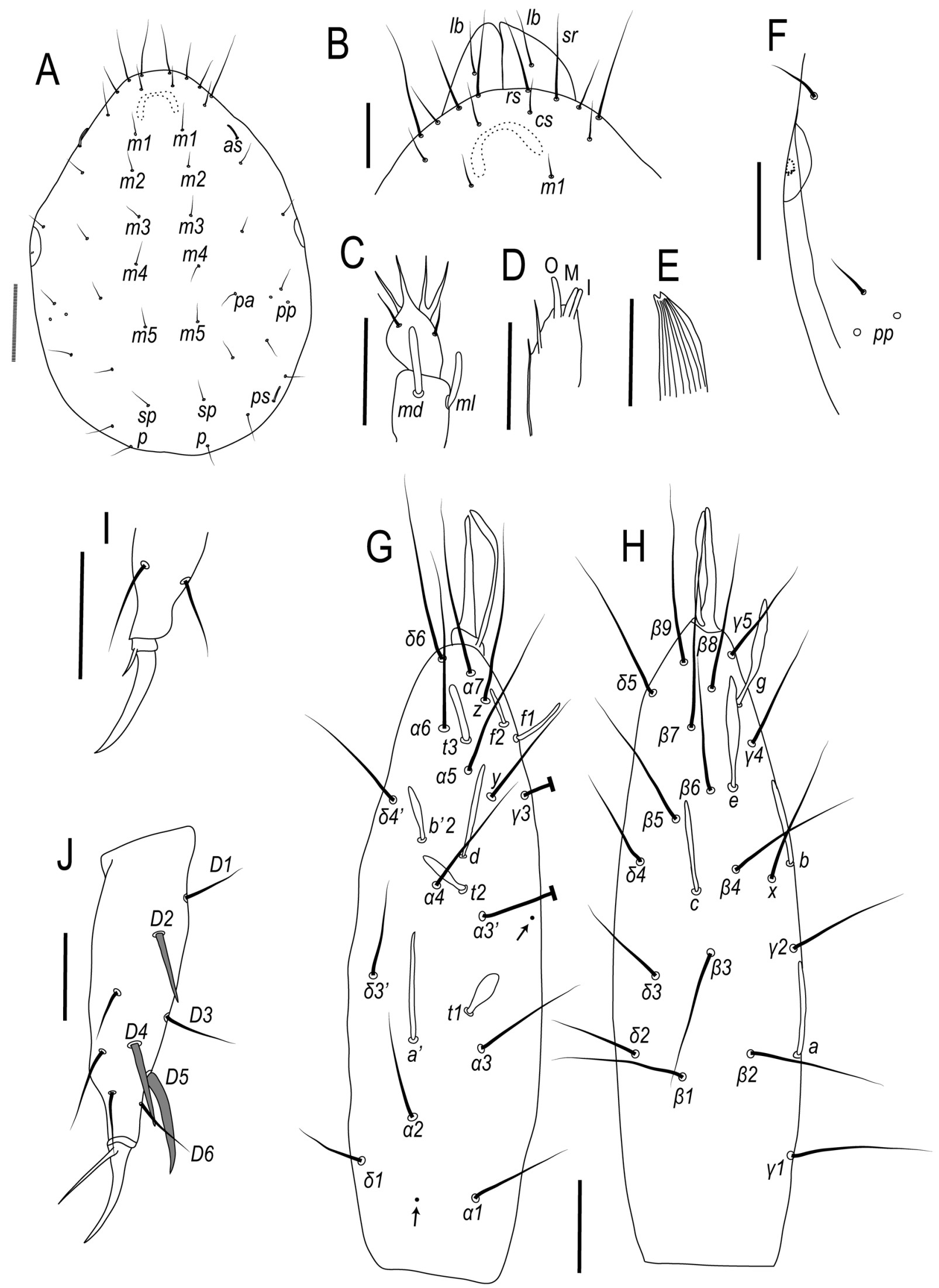

Fig.1. Eosentomon villare sp. nov., holotype, female (NSMT-Ap 539). A, Dorsal view of the head; B, labrum and rostral region; C, maxillary palpus; D, galea; E, mandible; F, pseudoculus; G, interior view of the foretarsus; H, exterior view of the foretarsus; I, distal part of the middle tarsus; J, dorsal view of the hind tarsus. Abbreviations: as, anterior sensillum; $c s$, clypeal seta; I, inner digit; $l b$, labral seta; $\mathrm{M}$, median digit; $m d$, dorsal sensillum; $m l$, lateral sensillum; $\mathrm{O}$, outer digit; $p$, median posterior seta; $p a$, posterior additional seta; $p p$, a pair of sensilla posterior to pseudoculus; $p s$, posterior sensillum; $r s$, rostral seta; $s p$, median subposterior seta; $s r$, subrostral seta. Arrows show pores. Scale bars: $10 \mu \mathrm{m}$. 

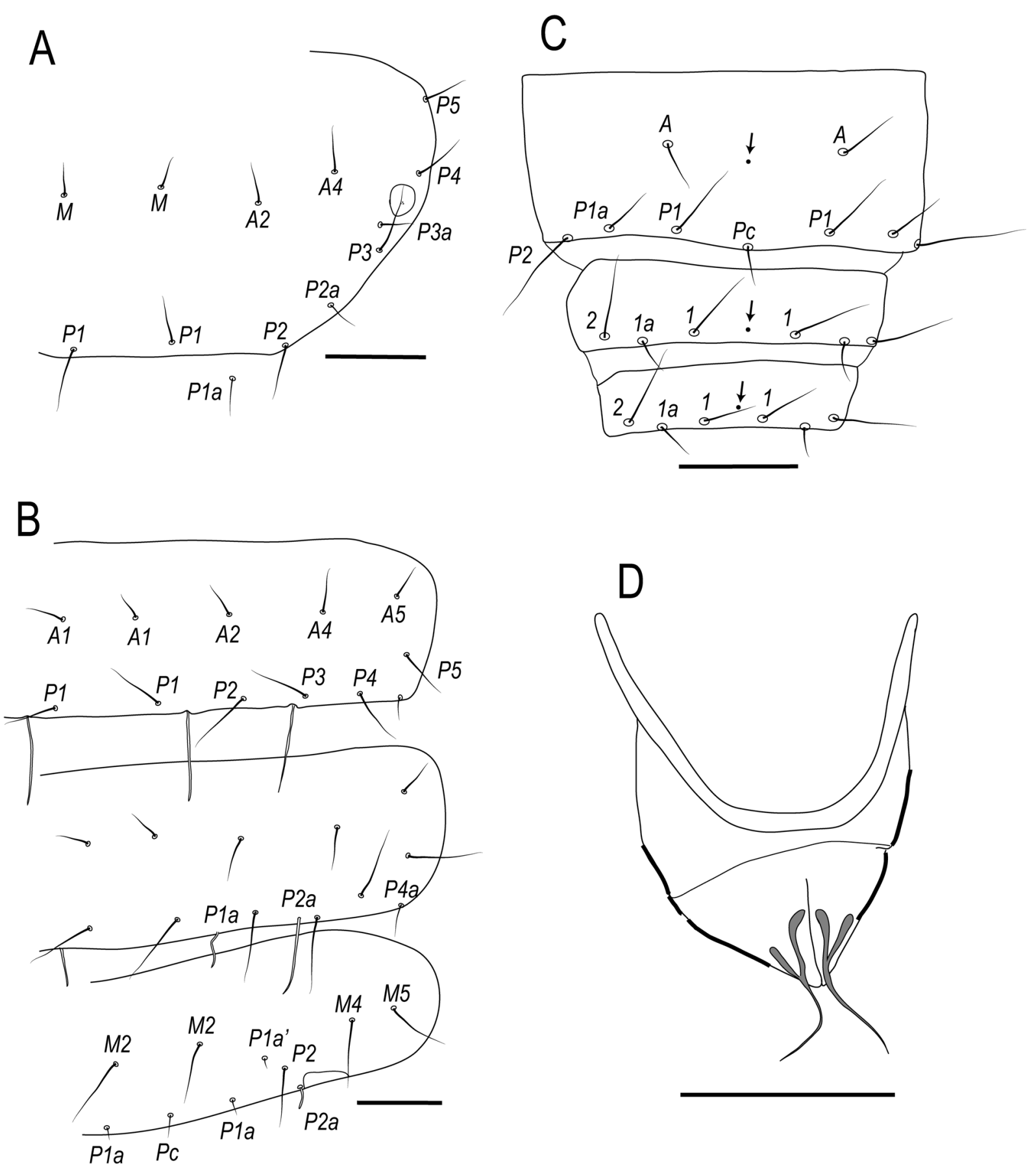

Fig. 2. Eosentomon villare sp. nov., holotype, female (NSMT-Ap 539). A, Dorsal view of thorax III, right side; B, dorsal view of abdomen VI-VIII, right side; C, ventral view of abdomen VIII-X; D, female squama genitalis. Arrows show pores. Scale bars: $20 \mu \mathrm{m}$.

posterior margin; sternite VIII with two anterior and seven posterior setae, IX-X with six setae.

Specimens examined. Holotype (NSMT-Ap 539): female, the Nasu Imperial Villa, Nasu-machi, Tochigi Prefecture, $37.1100^{\circ} \mathrm{N}, 140.0158^{\circ} \mathrm{E}$, elev. $919 \mathrm{~m}$, secondary forest dominated by Q. crispula and P. densiflora, 7 October 2011, K. Furuno et al. leg. Paratypes: two females (TPM-IV-14024; SMNH-Ap-36639), same data as for the holotype except sampling date, 15 October 2013.

Description. Body length. $663(598-676) \mu \mathrm{m}$.

Head. 94 (91-94) $\mu \mathrm{m}$ long, 70 (71-73) $\mu \mathrm{m}$ wide. Posterior additional setae and seta $m 4$ present, but anterior additional seta absent, anterior and posterior sensilla present (Fig. 1A); median subposterior seta $(s p)$ subequal to median posterior seta $(p)$ in length, $8(8) \mu \mathrm{m}$; one pair of sensilla $(p p)$ posterior to pseudoculus rudimentary. Labral setae present (Fig. 1B). Rostral seta normal, about equal to subrostral seta, 13 (12-13) $\mu \mathrm{m}$ in length (Fig. 1B). On maxillary palpus (Fig. $1 C)$, dorsal sensillum length $7 \mu \mathrm{m}$, longer than lateral sensillum, $5 \mu \mathrm{m}$. On galea (Fig. 1D), digit $\mathrm{O}$ slightly longer than $\mathrm{M}$ and I. Mandible with two teeth (Fig. 1E). Clypeal apodeme distinct (Fig. 1A, B). Pseudoculus with a central mark (Fig. 1F), 10 (10) $\mu \mathrm{m}$ long, $\mathrm{PR}=9$ (9).

Legs. Foretarsus length (Fig. 1G, H) 68 (68-70) $\mu \mathrm{m}$; claw 
Table 1. Chaetotaxy of Eosentomon villare sp. nov.

\begin{tabular}{|c|c|c|c|c|c|}
\hline & & \multicolumn{2}{|r|}{ Dorsal } & \multicolumn{2}{|c|}{ Ventral } \\
\hline & & Formula & Composition of setae & Formula & Composition of setae \\
\hline \multirow[t]{6}{*}{ Thorax } & I & 4 & 1,2 & $6-2$ & $\mathrm{~A} 1,2,3, \mathrm{M}$ \\
\hline & & & & 6 & $\mathrm{P} 1,2,3$ \\
\hline & II & 6 & $\mathrm{~A} 2,4, \mathrm{M}$ & $6-2$ & $\mathrm{~A} 1,2,3, \mathrm{M}$ \\
\hline & & 16 & $\mathrm{P} 1,1 \mathrm{a}, 2,2 \mathrm{a}, 3,3 \mathrm{a}, 4,5$ & 6 & $\mathrm{P} 1,2,3$ \\
\hline & III & 6 & $\mathrm{~A} 2,4, \mathrm{M}$ & 6-4 & $\mathrm{A} 1,2,3, \mathrm{M} 1,2$ \\
\hline & & 20 & $\mathrm{P} 1,1 \mathrm{a}, 2,2 \mathrm{a}, 3,3 \mathrm{a}, 4,5,5 \mathrm{a}, 5 \mathrm{a}^{\prime}$ & 8 & $\mathrm{P} 1,2,3,4$ \\
\hline \multirow[t]{11}{*}{ Abdomen } & I & 4 & $\mathrm{~A} 1,2$ & 4 & $\mathrm{~A} 1,2$ \\
\hline & & 12 & $\mathrm{P} 1,1 \mathrm{a}, 2,3,3 \mathrm{a}, 3 \mathrm{a}^{\prime}$ & 4 & $\mathrm{P} 1,2$ \\
\hline & II-IV & 10 & $\mathrm{~A} 1,2,3,4,5$ & 6 & $\mathrm{~A} 1,2,3$ \\
\hline & & 16 & $\mathrm{P} 1,1 \mathrm{a}, 2,2 \mathrm{a}, 3,4,4 \mathrm{a}, 5$ & 4 & $\mathrm{P} 1,2$ \\
\hline & V-VII & 8 & $\mathrm{~A} 1,2,4,5$ & 6 & $\mathrm{~A} 1,2,3$ \\
\hline & & 16 & $\mathrm{P} 1,1 \mathrm{a}, 2,2 \mathrm{a}, 3,4,4 \mathrm{a}, 5$ & 10 & $P 1,2,2 a, 2 a^{\prime}, 3$ \\
\hline & VIII & 6 & $\mathrm{M} 2,4,5$ & 2 & A \\
\hline & & 9 & Pc, $1 \mathrm{a}, 1 \mathrm{a}^{\prime}, 2,2 \mathrm{a}$ & 7 & Pc, $1,1 \mathrm{a}, 2$ \\
\hline & IX-X & 8 & $1,2,3,4$ & 6 & $1,1 \mathrm{a}, 2$ \\
\hline & XI & 8 & $1,2,3,4$ & 8 & $1,2,3,4$ \\
\hline & Telson & 9 & & 12 & \\
\hline
\end{tabular}

$12(13-14) \mu \mathrm{m}, \mathrm{TR}=5.7$ (4.9-5.3); empodium 11 (11) $\mu \mathrm{m}$, $\mathrm{EU}=0.9$ (0.8); sensillum $s$ length $16(14-16) \mu \mathrm{m}$, longer than claw. Sensillum $t 1$ nearer to $\alpha 3$ than to $\alpha 3^{\prime}, \mathrm{BS}=0.9$ (0.8); $t 2$ small, narrowly spatulate; $t 3$ slightly broadened, reaching base of $\alpha 7$; $a$ linear, not reaching base of $\gamma 2 ; b$ linear, reaching base of $\gamma 3 ; c$ linear, surpassing base of $\beta 5$; $d$ linear, reaching base of $\alpha 5$; $e$ and $g$ rounded spatulate and large; $f 1$ and $f 2$ thin, $f 2$ shorter than $f 1$; $a^{\prime}$ linear; $b^{\prime} 1$ absent; $b^{\prime} 2$ same as $t 2$, small, narrowly spatulate; $c^{\prime}$ absent. A pore between $\alpha 1$ and $\delta 1$, and between $b$ and $\alpha 3^{\prime}$. Length of middle tarsus 29 (28-33) $\mu \mathrm{m}$, length of claw 10 (11) $\mu \mathrm{m}$; empodium short and about 1/4 of claw in length (Fig. 1I), 3 (3) $\mu \mathrm{m}$ long; hind tarsus 36 (36-39) $\mu \mathrm{m}$, claw 11 (12) $\mu \mathrm{m}$; empodium longer than $2 / 3$ of claw in length (Fig. 1 J), 8 (8) $\mu \mathrm{m}$ long; on hind tarsus (Fig. 1J), D2 and D4 spine-like, more slender than D5.

Chaetotaxy. Chaetotaxy as in Table 1 and Fig. 2A-C. On thoracic tergites II-III (Fig. 2A), $P 1 a$ and $P 2 a$ seta-like, but shorter than $P 1$; $P 1 a$ posterior to $P 1-P 2$; $P 2$ a slightly closer to $P 2$ than to $P 3$; $P 1 a, 7$ (7-9) $\mu \mathrm{m}$ long, subequal or slightly longer than $P 2 a, 7$ (6-7) $\mu \mathrm{m}$ long. Abdominal tergites IIIV with five pairs of anterior setae ( $A 1$ to 5 ), V-VII with four pairs $(A 1,2,4,5) ; P 1 a$ on tergite $\mathrm{I}$, and $P 1 a$ and $P 2 a$ on II-VI delicate, longer than P1; P1a on VII short, about $1 / 2$ of $P 1$ in length, 9 (9) $\mu \mathrm{m}$ long, at hind margin; $P 2 a$ on VII subequal to $P 1$ in length (Fig. $2 \mathrm{~B}$ ); $P 1 a$ on I-VI nearer to $P 1$ than to $P 2 ; P 2 a$ on II-VII nearer to $P 3$ than to $P 2$; on VIII (Fig. 2B) $P 1 a^{\prime}$ normal and slightly anterior to $P 2, P 2 a^{\prime}$ short, linear. Setae on thoracic and abdominal sternites all seta-like; sternite VIII with two anterior and seven posterior setae; sternites IX-X with six setae (Fig. 2C).

Porotaxy. Abdominal tergites IX-X with a pair of pores near seta 1 . Abdominal sternites I-XI with one medial pore (Fig. 2C). Telson with two dorsal medial pores and one ventral medial pore.

Female squama genitalis (Fig. 2D). Caput processus blunt, slightly curved against median edge of stylus, corpus processus reduced except for well-developed alae processus; filum processus long and slender; proximo-lateral sclerotization present; stylus apex narrowly rounded.

Chaetotaxic variation. $P 4 a$ on abdominal tergites III-IV and $P 2 a$ on abdominal sternites VI-VII asymmetrically absent and asymmetrically present in one paratype female.

Remarks. The genus Eosentomon contains more than 280 species and is common in most areas of the world. Within this genus, the new species is similar to E. sociale Bernard, 1975, E. erwini Copeland, 1978 and E. quapawense Tipping and Allen, 1994 from the USA, and to E. notiale Tuxen and Imadaté, 1975 from the Solomon Islands, according to a combination of important features such as the absence of foretarsal sensillum $b^{\prime} 1$, the long empodium on the hind tarsus, and two anterior and seven posterior setae on sternite VIII (Bernard 1975; Tuxen and Imadaté 1975; Copeland 1978; Tipping and Allen 1994). This new species differs from these four established species, however, by the anterior setae on abdominal tergite VII (six setae in the four established species), the setae on abdominal sternites IX-X (four setae in the four established species but six on IX in E. quapawense), and the structure of the female squama genitalis.

Among the Japanese Eosentomon species, the new species is similar to E. udagawai Imadaté, 1961, E. dubium Nakamura, 2010, and E. inconditum Nakamura, 2010 in having a long empodium on the hind tarsus and two anterior and seven posterior setae on sternite VIII (Imadaté 1974; Nakamura 2010). However, the new species differs from these three established species by the absence of foretarsal sensillum $b^{\prime} 1$ (present in the three established species) and the structure of the female squama genitalis (duck's head-type caput processus in the three established species). Moreover, this new species is distinguished from E. udagawai by the labral setae (absent in E. udagawai) and the length of the empodium on the middle tarsus (about one-third of the 
claw length in E. udagawai), from E. dubium by the anterior setae on abdominal tergites V-VII (ten setae on V-VI and six on VII in E. dubium), and from E. inconditum by the anterior setae on abdominal tergite VII (six setae in $E$. inconditum). The following eight Japanese Eosentomon species also lack foretarsal sensillum $b^{\prime} 1$ : E. kumei Imadaté and Yosii, 1959, E. topochi Imadaté, 1964, E. toi Imadaté, 1964, E. brachychaetum Nakamura, 2010, E. kantoense Nakamura, 2010, E. spatulatum Nakamura, 2010, E. calvum Nakamura, 2010, and E. hiroshianum Nakamura, 2010; however, the new species is easily distinguishable from these as they have a short empodium on the hind tarsus (Imadate 1974; Nakamura 2010).

Distribution. Japan, known only from the type locality.

Etymology. The specific name is derived from the Nasu Imperial Villa, the type locality.

\section{Genus Pseudanisentomon Zhang and Yin, 1984 Pseudanisentomon nasuense sp. nov.} (Figs 3, 4; Table 2)

\section{Pseudanisentomon sp.: Nakamura 2019: 18 (partim).}

Diagnosis. Foretarsal sensillum $b^{\prime} 1$ absent, $d$ fairly broad, and $t 3$ long, reaching base of tarsal claw; long empodia on both middle and hind tarsi; abdominal tergites II-IV with five pairs of anterior setae, V-VII with four pairs of anterior setae $(A 1,2,4,5)$; sternites IX-X with six setae.

Specimens examined. Holotype (NSMT-Ap 540): female, the Nasu Imperial Villa, Nasu-machi, Tochigi Prefecture, $37.1102^{\circ} \mathrm{N}, 140.0152^{\circ} \mathrm{E}$, elev. $928 \mathrm{~m}$, secondary forest dominated by Q. crispula and P. densiflora, 5 September 2012, K. Furuno et al. leg. Paratypes $(\mathrm{n}=21)$ : one female (NSMT-Ap 541), same data as for the holotype; same locality as for the holotype, two males (NSMT-Ap 542, 543), 11 June 2012, one male and one female (NSMT-Ap 544, 545), 7 November 2012, one male and one female (NSMT-Ap 546, 547), 15 October 2013, K. Furuno et al. leg.; $37.1105^{\circ} \mathrm{N}, 140.0150^{\circ} \mathrm{E}$, elev. $929 \mathrm{~m}$, one male and one female (NSMT-Ap 548, 549), 11 June 2012, one male (NSMT-Ap 550), 7 November 2012, K. Furuno et al. leg.; $37.1102^{\circ} \mathrm{N}, 140.0161^{\circ} \mathrm{E}$, elev. $918 \mathrm{~m}$, one male and three females (TPM-IV-14025-14028), 11 June 2012, one male (TPM-IV-14029), 15 October 2013, one male (TPM-IV-14030), 27 October 2015, K. Furuno et al. leg.; $37.1100^{\circ} \mathrm{N}, 140.0158^{\circ} \mathrm{E}$, elev. $919 \mathrm{~m}$, one female (SMNH-Ap-36640), 7 October 2011, one female (SMNHAp-36641), 11 June 2012, one female (SMNH-Ap-36642), 7 November 2012, two males (SMNH-Ap-36643, 36644), 15 October 2013, K. Furuno et al. leg.

Other material examined $(n=17)$ : same locality as for the holotype, one female, 7 November 2012, one male and one female, 15 October 2013, one female and one maturus junior, 27 October $2015 ; 37.1105^{\circ} \mathrm{N}, 140.0150^{\circ} \mathrm{E}$, elev. $929 \mathrm{~m}$, one male and one female, 7 October 2011, one male and one female, 11 June 2012, one maturus junior, 7 November 2012 , one maturus junior, 15 October $2013 ; 37.1102^{\circ} \mathrm{N}$, $140.0161^{\circ} \mathrm{E}$, elev. $918 \mathrm{~m}$, two males, one female and one maturus junior; $37.1100^{\circ} \mathrm{N}, 140.0158^{\circ} \mathrm{E}$, elev. $919 \mathrm{~m}$, one male,
7 November 2012, one female, 27 October 2015.

Description. Body length. $722(592-780) \mu \mathrm{m}$.

Head. 99 (95-100) $\mu \mathrm{m}$ long, 67 (66-74) $\mu \mathrm{m}$ wide. Posterior additional setae and seta $m 4$ present, anterior additional seta absent; anterior and posterior sensilla present (Fig. 3A); median subposterior seta length 8 (7-9) $\mu \mathrm{m}, 1.1$ times longer than median posterior seta, $7(6-8) \mu \mathrm{m}$; a pair of rudimentary sensilla posterior to pseudoculus rudimentary. Labral setae present (Fig. 3B). Rostral seta length 11 (10-12) $\mu \mathrm{m}$, tapering, subequal to subrostral seta, $11(10-14) \mu \mathrm{m}$ in length (Fig. 3B). On maxillary palpus (Fig. 3C) dorsal sensillum length $6(5-7) \mu \mathrm{m}$, longer than lateral sensillum, 4 (4-6) $\mu \mathrm{m}$. On galea (Fig. 3D), digit O longer than $\mathrm{M}$ and I. Mandible with two teeth (Fig. 3E). Clypeal apodeme distinct (Fig. 3B). Pseudoculus with three lines, central one long and other two short (Fig. 3F), 7 (7-9) $\mu \mathrm{m}$ long, $\mathrm{PR}=15$ (12-15).

Legs. Foretarsus length (Fig. 3G, H) 64 (61-67) $\mu \mathrm{m}$; claw $12(11-13) \mu \mathrm{m}, \mathrm{TR}=5.0$ (4.7-5.5); empodium 12 (11-13) $\mu \mathrm{m}, \mathrm{EU}=1.0(0.9-1.1)$; sensillum $s$ length about equal to claw, $11(11-13) \mu \mathrm{m}$. Sensillum $t 1$ nearer to $\alpha 3$ than to $\alpha 3^{\prime}$, $\mathrm{BS}=0.9(0.9-1.0)$; $t 2$ thin; $t 3$ broad, reaching base of tarsal claw; $a$ linear; $b$ linear, reaching base of $\beta 6$; $c$ linear, reaching base of $\gamma 3$; $d$ fairy broad, reaching base of $\alpha 5$; $e$ absent; $f 1$ narrowly spatulate; $f 2$ linear; $g$ rounded spatulate and large; $a^{\prime}$ linear; $b^{\prime} 1$ absent; $b^{\prime} 2$ and $c^{\prime}$ thin, almost same length. A pore posterior to seta $y$. Length of middle tarsus 27 (26-30) $\mu \mathrm{m}$, length of claw $10(8-11) \mu \mathrm{m}$; hind tarsus $33(33-37)$ $\mu \mathrm{m}$, claw $11(8-10) \mu \mathrm{m}$; both empodia long, about $2 / 3$ of claw length on middle tarsus, 7 (5-8) $\mu \mathrm{m}$ long (Fig. 3I); empodium longer than $2 / 3$ of claw length on hind tarsus (Fig. 3J), 9 (7-9) $\mu \mathrm{m}$ long; on hind tarsus (Fig. 3J), D2 seta-like; D4 spine-like, but more slender than D5.

Chaetotaxy. Chaetotaxy as in Table 2 and Fig. 4A-D. On thoracic tergites II-III (Fig. $4 \mathrm{~A}$ ), $P 1 a$ and $P 2 a$ seta-like; $P 1 a$ posterior to $P 1-P 2 ; P 2 a$ on II slightly nearer to $P 2$ than to $P 3$; $P 2 a$ on III halfway between $P 2$ and $P 3 ; P 1 a$ and $P 2 a$ on II-III shorter than P1; on II P1a 8 (7-10) $\mu \mathrm{m}$, slightly longer than P2a, 7 (5-7) $\mu \mathrm{m}$; on III P1a 7 (9-11) $\mu \mathrm{m}$, length subequal to or slightly longer than $P 2 a, 7$ (7-9) $\mu \mathrm{m}$. Abdominal tergites II-IV with five pairs of anterior setae (A1 to 5), V-VII with four pairs $(A 1,2,4,5) ; P 1 a$ on I, $P 1 a$ and $P 2 a$ on II-VI and $P 2 a$ on VII delicate, longer than $P 1 ; P 1 a$ on VII short, about $1 / 3$ of $P 1$ in length, $5(4-7) \mu \mathrm{m}$ long, at hind margin (Fig. 4B); on VIII (Fig. 4C) $P 1 a^{\prime}$ with basal dilatation and slightly anterior to $P 2, P 2 a^{\prime}$ falcate. Setae on thoracic and abdominal sternites all seta-like; VIII with two anterior and seven posterior setae; IX-X with six setae (Fig. 4D).

Porotaxy. Abdominal tergites $\mathrm{I}-\mathrm{V}$ with posterosubmedial pore between $A 2$ and $P 2$; IX-X with one medial pore (Fig. $4 \mathrm{C}$ ). Abdominal sternites VIII-X with one medial pore (Fig. $4 \mathrm{D})$. Telson with one dorsal medial pore and two ventral medial pores.

Genitalia. Female squama genitalis (Fig. 4E), with caput processus shaped like a duck's head, filum processus short; proximo-lateral sclerotization present; posterior sclerotization of stylus apex present. Male squama genitalis with short basiperiphallar setae (Fig. 4F).

Maturus junior $(\mathrm{n}=4)$. Body length $580-618 \mu \mathrm{m}$. Head 

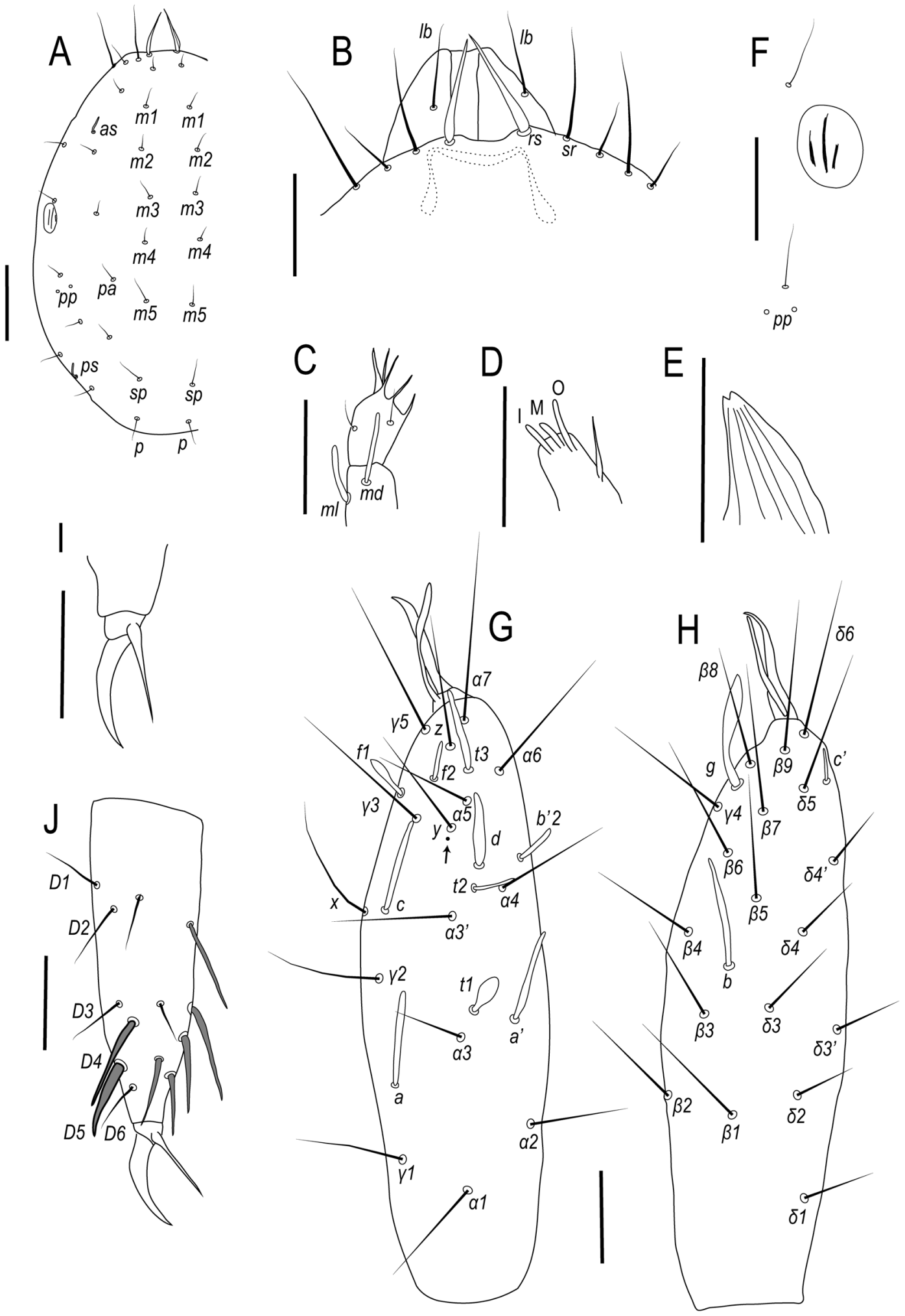

Fig. 3. Pseudanisentomon nasuense sp. nov., holotype, female (NSMT-Ap 540). A, Dorsal view of the head; B, labrum and rostral region; C, maxillary palpus; D, galea; E, mandible; F, pseudoculus; G, interior view of foretarsus; $\mathrm{H}$, exterior view of the foretarsus; I, distal part of the middle tarsus; J, dorsal view of the hind tarsus. Abbreviations: $a$, anterior sensillum; I, inner digit; $l b$, labral seta; $\mathrm{M}$, median digit; $m d$, dorsal sensillum; $m l$, lateral sensillum; $\mathrm{O}$, outer digit; $p$, median posterior seta; $p a$, posterior additional seta; $p p$, a pair of sensilla posterior to pseudoculus; $p s$, posterior sensillum; $r$, rostral seta; $s p$, median subposterior seta; $s r$, subrostral seta. Arrow shows pore. Scale bars: $20 \mu \mathrm{m}$ in A; $10 \mu \mathrm{m}$ for all other images. 

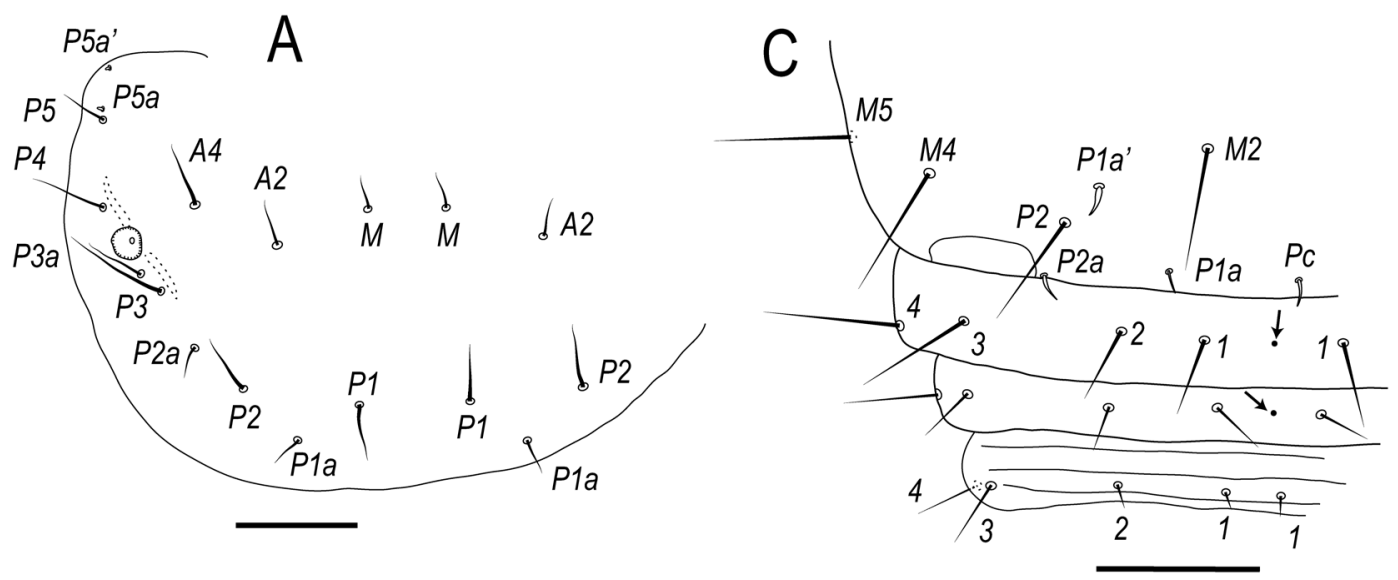

B
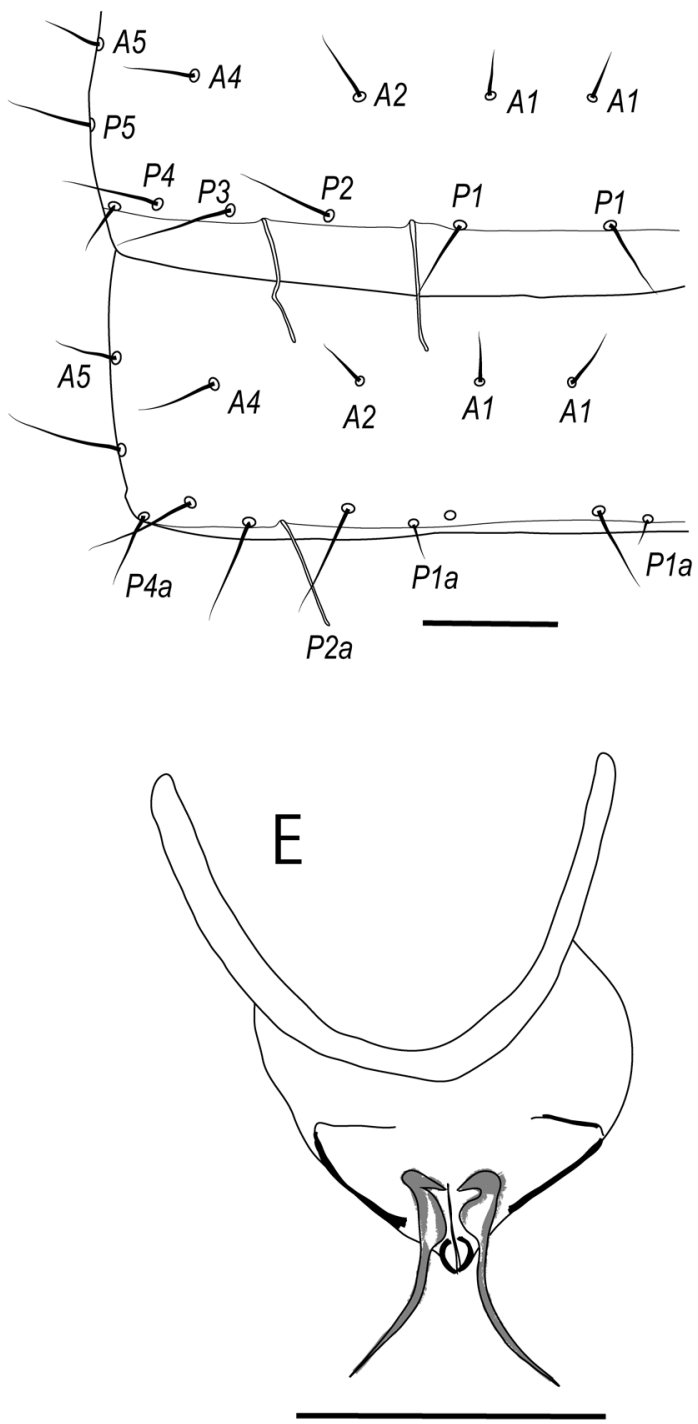

D
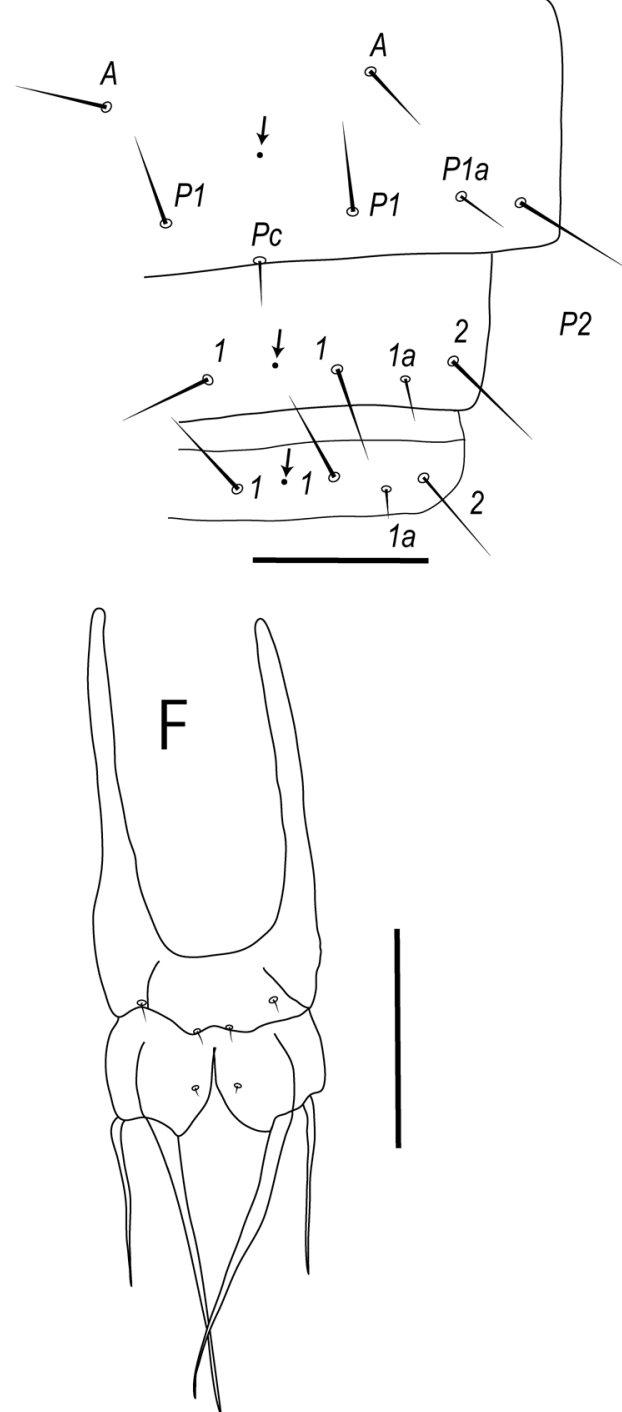

Fig. 4. Pseudanisentomon nasuense sp. nov. A, Dorsal view of thorax III, right side; B, dorsal view of abdomen VI-VII, left side; C, dorsal view of abdomen VIII-XI, left side; D, ventral view of abdomen VIII-X, right side; E, female squama genitalis; F, male squama genitalis. Arrows show pores. A-D, Holotype, female (NSMT-Ap 539); F, paratype, male (SMNH-Ap-36643). Scale bars: $20 \mu$ m. 
Table 2. Chaetotaxy of Pseudanisentomon nasuense sp. nov.

\begin{tabular}{|c|c|c|c|c|c|}
\hline & & \multicolumn{2}{|c|}{ Maturus junior } & \multicolumn{2}{|c|}{ Imago } \\
\hline & & Formula & Composition of setae & Formula & Complementary setae \\
\hline \multicolumn{6}{|l|}{ (Dorsal) } \\
\hline \multirow[t]{5}{*}{ Thorax } & I & 4 & 1,2 & 4 & \\
\hline & II & 6 & $\mathrm{~A} 2,4, \mathrm{M}$ & 6 & \\
\hline & & 16 & $\mathrm{P} 1,1 \mathrm{a}, 2,2 \mathrm{a}, 3,3 \mathrm{a}, 4,5$ & 16 & \\
\hline & III & 6 & $\mathrm{~A} 2,4, \mathrm{M}$ & 6 & \\
\hline & & 20 & $\mathrm{P} 1,1 \mathrm{a}, 2,2 \mathrm{a}, 3,3 \mathrm{a}, 4,5,5 \mathrm{a}, 5 \mathrm{a}^{\prime}$ & 20 & \\
\hline \multirow[t]{10}{*}{ Abdomen } & I & 4 & $\mathrm{~A} 1,2$ & 4 & \\
\hline & & 12 & $\mathrm{P} 1,1 \mathrm{a}, 2,3,3 \mathrm{a}, 3 \mathrm{a}^{\prime}$ & 12 & \\
\hline & II-IV & 10 & $\mathrm{~A} 1,2,3,4,5$ & 10 & \\
\hline & & 16 & $\mathrm{P} 1,1 \mathrm{a}, 2,2 \mathrm{a}, 3,4,4 \mathrm{a}, 5$ & 16 & \\
\hline & V-VII & 8 & $\mathrm{~A} 1,2,4,5$ & 8 & \\
\hline & & 16 & $\mathrm{P} 1,1 \mathrm{a}, 2,2 \mathrm{a}, 3,4,4 \mathrm{a}, 5$ & 16 & \\
\hline & VIII & 6 & $\mathrm{M} 2,4,5$ & 6 & \\
\hline & & 9 & Pc, 1a, 1a', 2, 2a & 9 & \\
\hline & IX-XI & 8 & $1,2,3,4$ & 8 & \\
\hline & Telson & 9 & & 9 & \\
\hline \multicolumn{6}{|l|}{ (Ventral) } \\
\hline \multirow[t]{4}{*}{ Thorax } & I-II & $6-2$ & $\mathrm{~A} 1,2,3, \mathrm{M}$ & $6-2$ & \\
\hline & & 6 & $\mathrm{P} 1,2,3$ & 6 & \\
\hline & III & $6-4$ & $\mathrm{~A} 1,2,3, \mathrm{M} 1,2$ & $6-4$ & \\
\hline & & 8 & $\mathrm{P} 1,2,3,4$ & 8 & \\
\hline \multirow[t]{12}{*}{ Abdomen } & I & 4 & $\mathrm{~A} 1,2$ & 4 & \\
\hline & & 4 & $\mathrm{P} 1,2$ & 4 & \\
\hline & II-III & 6 & $\mathrm{~A} 1,2,3$ & 6 & \\
\hline & & 4 & $\mathrm{P} 1,2$ & 4 & \\
\hline & IV-VII & 6 & $\mathrm{~A} 1,2,3$ & 6 & \\
\hline & & 10 & $\mathrm{P} 1,2,2 \mathrm{a}, 2 \mathrm{a}^{\prime}, 3$ & 10 & \\
\hline & VIII & 2 & A & 2 & \\
\hline & & 7 & Pc, $1,1 \mathrm{a}, 2$ & 7 & \\
\hline & IX & 6 & $1,1 \mathrm{a}, 2$ & 6 & \\
\hline & $\mathrm{X}$ & 4 & 1,2 & 6 & 1a \\
\hline & XI & 4 & 1,3 & 8 & 2,4 \\
\hline & Telson & 12 & & 12 & \\
\hline
\end{tabular}

91-94 $\mu \mathrm{m}$ long, 63-74 $\mu \mathrm{m}$ wide; pseudoculus $7-8 \mu \mathrm{m}$ long, $\mathrm{PR}=11-14$. Foretarsus length $56-59 \mu \mathrm{m}$; claw $10-11 \mu \mathrm{m}$, $\mathrm{TR}=5.0-5.6$; empodium $9-10 \mu \mathrm{m}, \mathrm{EU}=0.8-1.0$; sensillum $s 9-11 \mu \mathrm{m}$; shape and position of foretarsal sensilla same as those of imago, $B S=0.8-0.9$. Length of middle tarsus $27 \mu \mathrm{m}$, length of claw $8-10 \mu \mathrm{m}$, empodium $5-6 \mu \mathrm{m}$; hind tarsus 29-33 $\mu \mathrm{m}$, claw $10-11 \mu \mathrm{m}$, empodium $7-10 \mu \mathrm{m}$. Chaetotaxy as in imago, but lacking P1a on abdominal sternite IX and 2 and 4 on sternite XI.

Chaetotaxic variation. $P c$ on abdominal sternite VIII absent in one female; $A 2$ on abdominal tergite III asymmetrically absent in one male; $P 2 a^{\prime}$ on abdominal sternites VI and VII absent and asymmetrically absent in one maturus junior, respectively.

Remarks. The genus Pseudanisentomon is distributed in China and Japan, and consists of 22 species, of which 18 are from China and four are from Japan (Yin 1999; Nakamura 2010; Bu et al. 2020). The new species resembles $P$. songkiangensis (Yin, 1977), P. guangxiensis (Yin and Zhang, 1982), P. huichouense Zhang and Yin, 1984, and P. jiangxiensis Yin, 1987 from China by the absence of foretarsal sensillum $b^{\prime} 1$ and long empodia on both the middle and hind tarsus. However, the new species differs from $P$. songkiangensis, $P$. huichouense, and P. jiangxiensis by the five pairs of anterior setae on abdominal tergite IV (four pairs of anterior setae in the three established species), and from P. guangxiensis and $P$. huichouense by having six setae on abdominal sternites IX-X (four setae in these two established species). Moreover, the new species is distinguished from P. songkiangensis by having five pairs of anterior setae on abdominal tergites II-III (four pairs of anterior setae in P. songkiangensis), from $P$. jiangxiensis by the length of foretarsal sensilla $a$ and $c$ (short in P. jiangxiensis), from $P$. guangxiensis by the length of sensilla $t 2$ and $f 2$ on the foretarsus (not short in P. guangxiensis), and from P. huichouense by the shape and length of foretarsal sensillum $t 3$ (not broad and short in $P$. huichouense).

Distribution. Japan, known only from the Nasu Imperial Villa.

Etymology. The specific name is derived from the name of the district, Nasu-machi, where Nasu Imperial Villa of the type locality is located. 
Pseudanisentomon villaticum sp. nov. (Figs 5-8; Table 3)

Pseudanisentomon sp.: Nakamura 2019: 18 (partim).

Diagnosis. Foretarsal sensilla $b^{\prime} 1, c^{\prime}$ and seta $x$ absent, $a$ nearer to $\gamma 1$ than to $\gamma 2, f 1$ broad and long; long empodium on hind tarsus; abdominal tergite VII with three pairs of anterior setae $(A 2,4,5), 1$ and 2 rudimentary on $\mathrm{X}$; sternites IX-X with six setae.

Specimens examined. Holotype: female (NSMT-Ap 551), the Nasu Imperial Villa, Nasu-machi, Tochigi Prefecture, $37.1100^{\circ} \mathrm{N}, 140.0158^{\circ} \mathrm{E}$, elev. $919 \mathrm{~m}$, secondary forest dominated by Q. crispula and P. densiflora, 15 October 2013, K. Furuno et al. leg. Paratypes $(n=10)$ : one female (NSMT-Ap 552), same data as for the holotype; same locality as for the holotype, two males (NSMT-Ap 553, 554), 7 October 2011, one female (NSMT-Ap 555), 11 June 2012, one male, one female (TPM-IV-14031, 14032), 7 December 2012, one male (TPM-IV-14033), 27 October 2015, K. Furuno et al. leg. ; $37.1102^{\circ} \mathrm{N}, 140.0152^{\circ} \mathrm{E}$, elev. $928 \mathrm{~m}$, one male (SMNH-Ap-36645), 27 October 2015, K. Furuno et al. leg.; $37.1105^{\circ} \mathrm{N}, 140.0150^{\circ} \mathrm{E}$, elev. $929 \mathrm{~m}$, one male (SMNH-Ap-36646), 15 October 2013, K. Furuno et al. leg.; $37.1102^{\circ} \mathrm{N}, 140.0161^{\circ} \mathrm{E}$, elev. $918 \mathrm{~m}$, one female (SMNHAp-36647), 15 October 2013, K. Furuno et al. leg.

Other material examined $(n=18)$ : one female and one larva II, same data as for the holotype; same locality as for the holotype, one female and one larva II, 7 October 2011, one larva II and one larva I, 5 September 2012, one larva II, 7 November 2012, one female and one larva II, 15 October 2013, one larva II, 17 October $2015 ; 37.1102^{\circ} \mathrm{N}, 140.0152^{\circ} \mathrm{E}$, elev. $928 \mathrm{~m}$, one male, 27 October 2015; $37.1105^{\circ} \mathrm{N}$, $140.0150^{\circ} \mathrm{E}$, elev. $929 \mathrm{~m}$, one male and one larva II, 11 December 2011, one female, 7 November $2013 ; 37.1102^{\circ} \mathrm{N}$, $140.0161^{\circ} \mathrm{E}$, elev. $918 \mathrm{~m}$, one male, 11 December 2011, one female, 15 October 2013, two females, 27 October 2015.

Description. Body length. $663(592-715) \mu \mathrm{m}$.

Head. 102 (96-104) $\mu \mathrm{m}$ long, 68 (69-72) $\mu \mathrm{m}$ wide. Anterior and posterior additional setae, and seta $m 4$ present; anterior and posterior sensilla present (Fig. 5A); median subposterior seta length, 8 (7-9) $\mu \mathrm{m}, 1.2$ times longer than median posterior seta, 7 (7) $\mu \mathrm{m}$; a pair of rudimentary sensilla posterior to pseudoculus rudimentary. Labral setae present (Fig. $5 \mathrm{~B})$. Rostral seta length $13(11-13) \mu \mathrm{m}$, longer than subrostral seta, 11 (10-12) $\mu \mathrm{m}$, (Fig. 5B). On maxillary palpus (Fig. 5C) dorsal sensillum $(m d), 6(5-6) \mu \mathrm{m}$, longer than lateral sensillum $(m l), 4(4-5) \mu \mathrm{m}$. On galea (Fig. 5D), all digits similar in
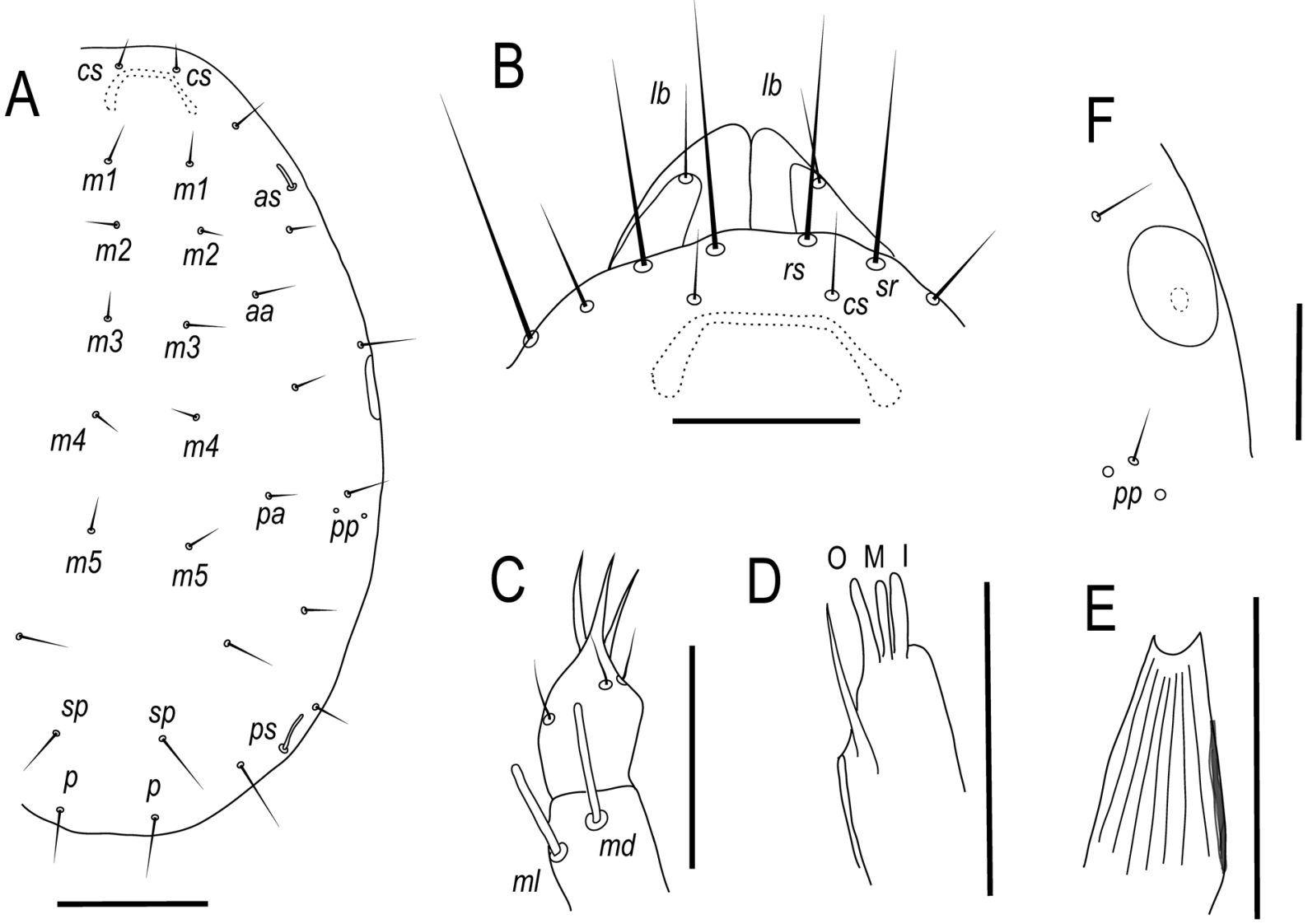

Fig. 5. Pseudanisentomon villaticum sp. nov. A, Dorsal view of the head; B, labrum and rostral region; C, maxillary palpus; D, galea; E, mandible; F, pseudoculus. A-C, F, Holotype, female (NSMT-Ap 551); D and E, paratype, female (NSMT-Ap 555); F, paratype, female (SMNH-Ap-36647). Abbreviations: $a a$, anterior additional seta; $a$, anterior sensillum; $c s$, clypeal seta; I, inner digit; $l b$, labral seta; M, median digit; $m d$, dorsal sensillum; $m l$, lateral sensillum; $\mathrm{O}$, outer digit; $p$, median posterior seta; $p a$, posterior additional seta; $p p$, a pair of sensilla posterior to pseudoculus; $p s$, posterior sensillum; $r s$, rostral seta; $s p$, median subposterior seta; $s r$, subrostral seta. Scale bars: $20 \mu \mathrm{m}$ in A; $10 \mu \mathrm{m}$ for all other images. 


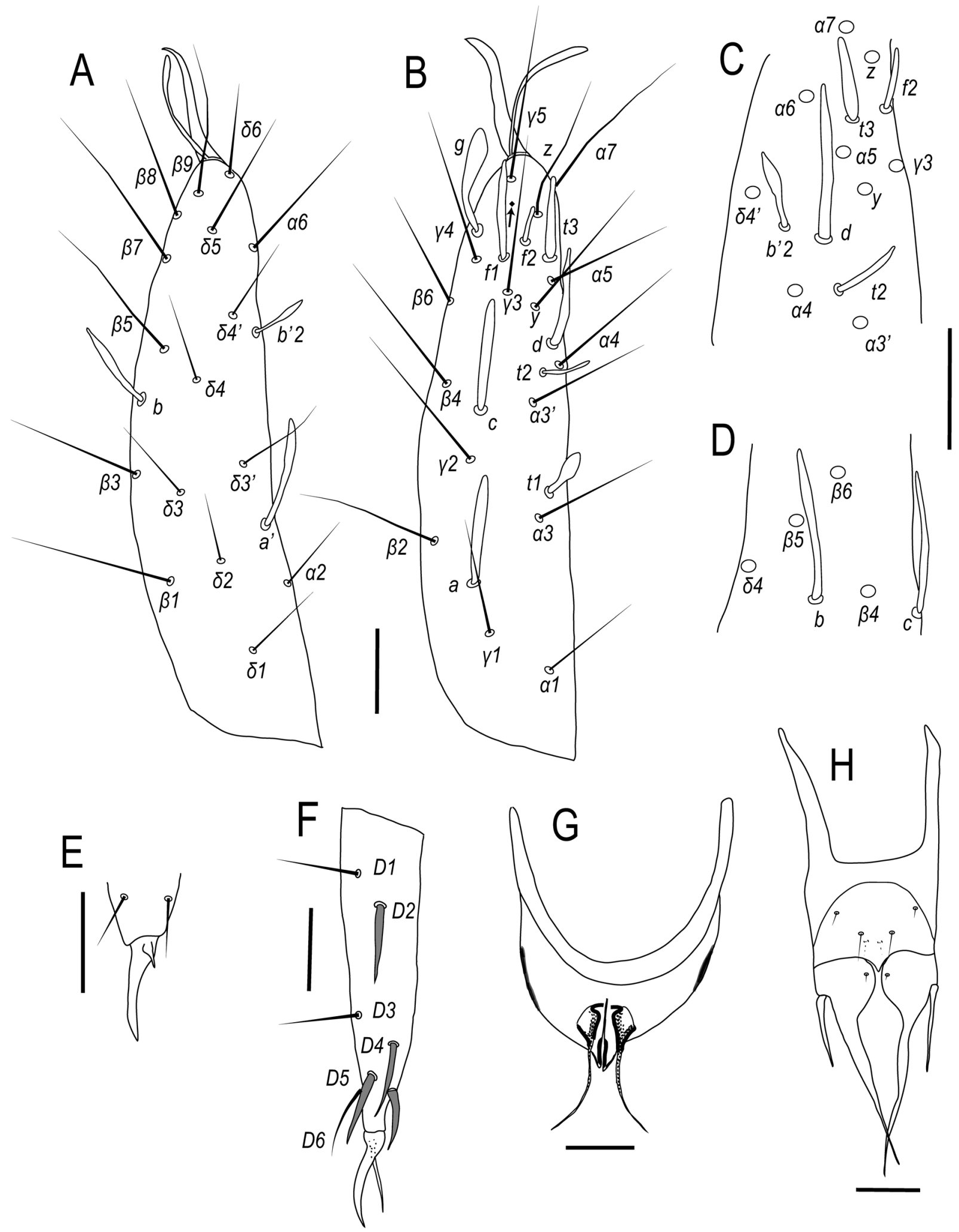

Fig. 6. Pseudanisentomon villaticum sp. nov. A, Exterior view of the foretarsus; B, interior view of the foretarsus; C, distal part of the interior view of the foretarsus; $\mathrm{D}$, central part of the exterior view of the foretarsus; $\mathrm{E}$, distal part of the middle tarsus; $\mathrm{F}$, dorsal view of the hind tarsus; G, female squama genitalis; H, male squama genitalis. Arrow shows pore. A, B, and E-G, Holotype, female (NSMT-Ap 551); C and D, paratype, male (NSMT-Ap 554); H, paratype, male (NSMT-Ap 553). Scale bars: $10 \mu \mathrm{m}$.

shape and length. Mandible with two teeth (Fig. 5E). Clypeal apodeme distinct (Fig. 5A, B). Pseudoculus with a weak central mark (Fig. 5F), 9 (8-11) $\mu \mathrm{m}$ long, $\mathrm{PR}=12$ (10-13).

Legs. Foretarsus length (Fig. 6A-D) 68 (63-68) $\mu \mathrm{m}$; claw
$12(12-13) \mu \mathrm{m}, \mathrm{TR}=5.8(4.9-5.7)$; empodium $12(12-13)$ $\mu \mathrm{m}, \mathrm{EU}=1.0(0.9-1.0)$; sensillum $s$ longer than claw, 15 (14-16) $\mu \mathrm{m}$. Sensillum $t 1$ nearer to $\alpha 3$ than to $\alpha 3^{\prime}, \mathrm{BS}=0.9$ (0.8-0.9); $t 2$ thin; $t 3$ broad, surpassing base of $\alpha 7$; $a$ broad, 

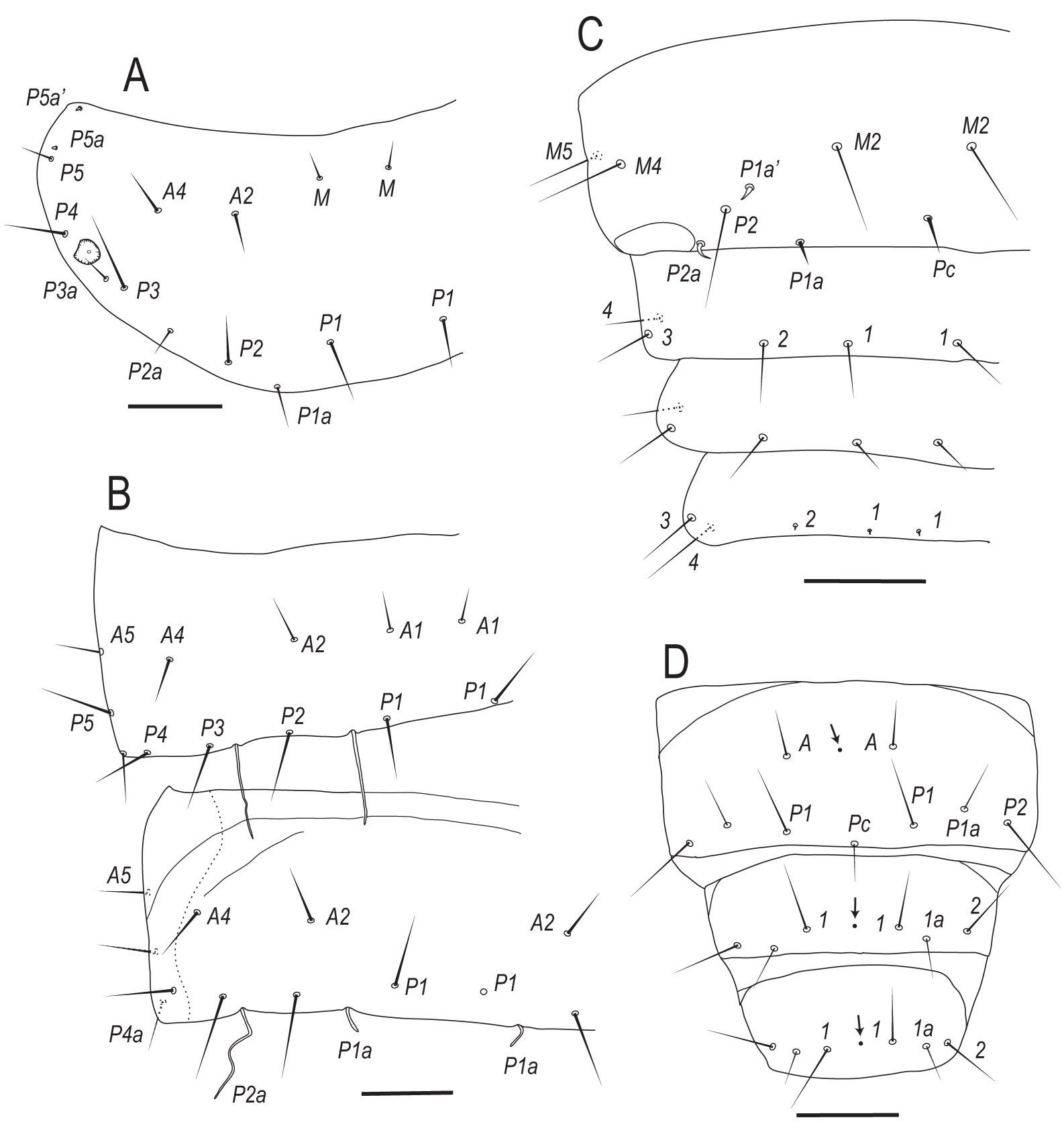

Fig. 7. Pseudanisentomon villaticum sp. nov., holotype, female (NSMT-Ap 551). A, Dorsal view of thorax III; B, dorsal view of abdomen VI-VII; C, dorsal view of abdomen VIII-XI; D, ventral view of abdomen VIII-X. Arrows show pores. Scale bars: $20 \mu \mathrm{m}$.

slightly closer to $\gamma 1$ than to $\gamma 2 ; b$ narrowly spatulate, surpassing base of $\beta 6$; $c$ broad, almost reaching base of $\gamma 3$; $d$ broad, reaching base of $t 3$; $e$ absent; $g$ rounded spatulate and large; $f 1$ broad, surpassing base of $\gamma 5 ; f 2$ thin; $a^{\prime}$ slightly broad; $b^{\prime} 1$ absent; $b^{\prime} 2$ small, narrowly spatulate; $c^{\prime}$ absent; seta $x$ absent. A pore posterior to $\gamma 5$. Length of middle tarsus $32(31-33) \mu \mathrm{m}$, length of claw $10(10-11) \mu \mathrm{m}$, empodium short, about $1 / 5$ of claw length, 2 (2) $\mu \mathrm{m}$ (Fig. $6 \mathrm{E}$ ); hind tarsus 39 (37-39) $\mu \mathrm{m}$, claw 11 (10-11) $\mu \mathrm{m}$; empodium longer than $2 / 3$ of claw length (Fig. $6 \mathrm{~F}$ ), 7 (7-9) $\mu \mathrm{m}$ long; on hind tarsus (Fig. 6F), D2 and D4 spine-like.

Chaetotaxy. Chaetotaxy as in Table 3 and Fig. 7A-D. On thoracic tergites II-III (Fig. 7A), $P 1 a$ and $P 2 a$ seta-like; $P 1 a$ posterior to $P 1-P 2$; $P 2 a$ on II slightly nearer to $P 2$ than to $P 3$; $P 2 a$ on III halfway between $P 2$ and $P 3$ or slightly nearer to
$P 2$ than to P3; on II P1a length $9(8-10) \mu \mathrm{m}$, shorter than $P 1,11(10-11) \mu \mathrm{m}$; on III $P 1 a$ length $9(9-10) \mu \mathrm{m}$, subequal to $P 1,11(10-11) \mu \mathrm{m} ; P 2 a$ on II-III 7 (5-7) and $8(6-8) \mu \mathrm{m}$, respectively, shorter than $P 1 a$. Abdominal tergites II-IV with five pairs of anterior setae (A1-5), V-VI with four pairs (A1, 2, 4, 5); VII with three pairs $(A 2,4,5)$; IX-X with 4 setae, but 1 and 2 on X rudimentary (Fig. 7C). P1a on abdominal tergite I, $P 1 a$ and $P 2 a$ on II-VI and $P 2 a$ on VII delicate and longer than $P 1$, but $P 2 a$ on VII subequal to $P 1$ in length; $P 1 a$ on VII short, $1 / 3-1 / 4$ of $P 1$ in length, $5(5-6) \mu \mathrm{m}$ long, at hind margin (Fig. 7B); on VIII (Fig. 7C), $P 1 a^{\prime}$ falcate and slightly anterior to $P 2, P 2 a^{\prime}$ falcate. Setae on thoracic and abdominal sternites all normal; VIII with two anterior and seven posterior setae; IX-X with six setae (Fig. 7D).

Porotaxy. Abdominal sternites VIII-X with one medial 

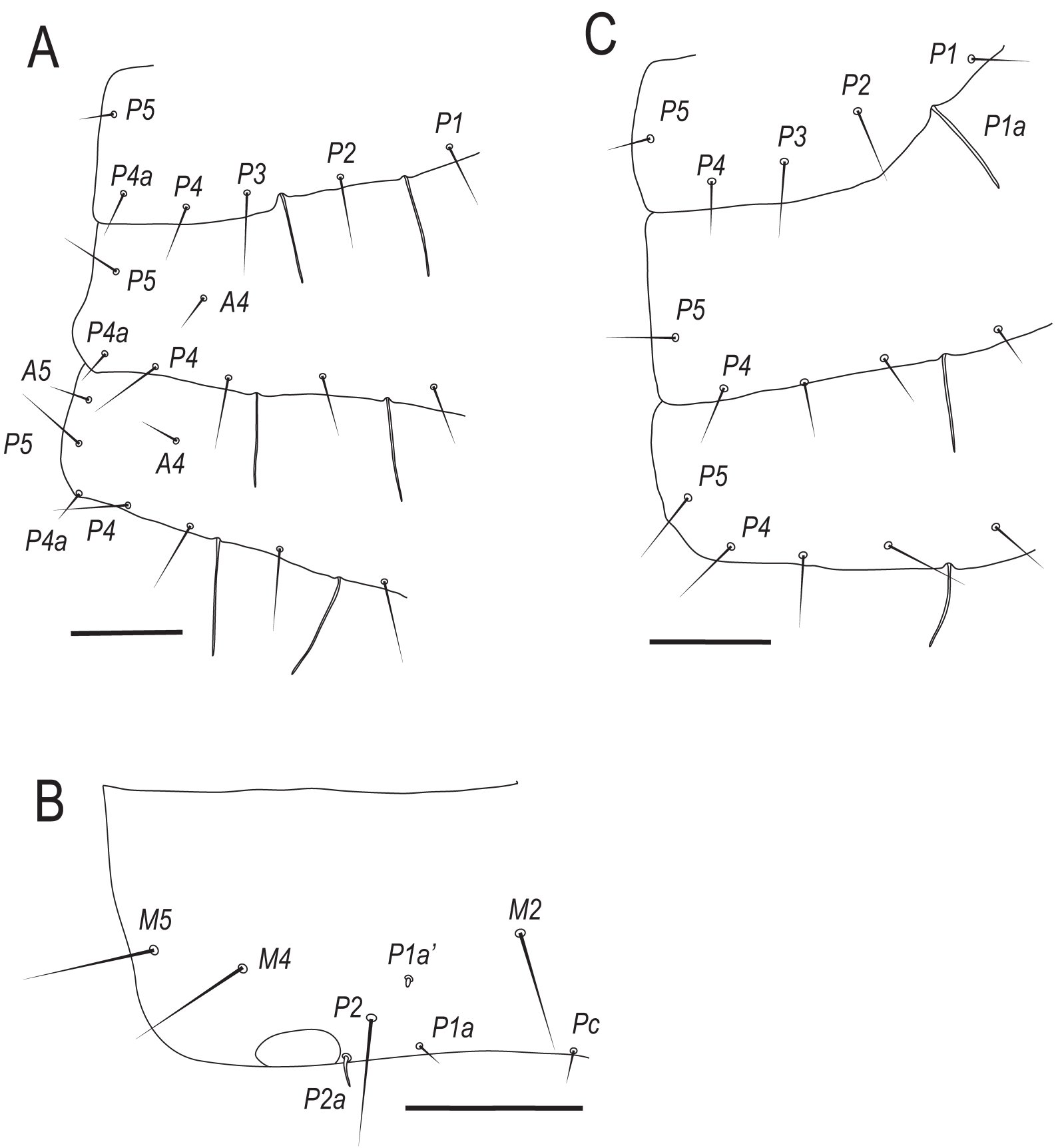

Fig. 8. Larval chaetotaxy of Pseudanisentomon villaticum sp. nov. A, Dorsal view of abdomen II-IV of Larva II; B, dorsal view of abdomen VIII of Larva II; C, dorsal view of abdomen II-IV of Larva I. Scale bars: $20 \mu \mathrm{m}$.

pore (Fig. 7D). Telson with one ventral medial pore.

Genitalia. On female squama genitalis (Fig. 6G) caput processus bent against the median edge of stylus in a sharp angle, outer and inner edges of corpus processus sclerotized; filum processus long; proximo-lateral sclerotization present; median sclerotization at posterior part of stylus. Male squama genitalis with short basiperiphallar setae (Fig. 6H).

Larva II $(\mathrm{n}=7)$. Body length $488-559 \mu \mathrm{m}$. Head length $85-95 \mu \mathrm{m}$; pseudoculus $8-9 \mu \mathrm{m}$ long, $\mathrm{PR}=11$. Foretarsus length $59-60 \mu \mathrm{m}$; claw $11-12 \mu \mathrm{m}$, $\mathrm{TR}=4.5-5.0$; empodium10-12 $\mu \mathrm{m}, \mathrm{EU}=0.9-1.0$; sensillum $s 14 \mu \mathrm{m}$; shape and position of foretarsal sensilla same as those of imago; $B S=0.8-$ 0.9. Length of middle tarsus $25-26 \mu \mathrm{m}$, length of claw $9 \mu \mathrm{m}$, empodium $2 \mu \mathrm{m}$ long; hind tarsus $31-33 \mu \mathrm{m}$, claw 9-10 $\mu \mathrm{m}$, empodium $5-8 \mu \mathrm{m}$. $P 5$ on abdominal tergites II and III displaced anteriorly and at same level with $A 4$ on III (Fig. 8A). $P 1 a$ on abdominal tergite VIII distal to P2 (Fig. 8B).

Larva $I(\mathrm{n}=1)$. Body length $462 \mu \mathrm{m}$. Head $91 \mu \mathrm{m}$ long; pseudoculus indistinct. Foretarsus length $54 \mu \mathrm{m}$; claw $11 \mu \mathrm{m}, \mathrm{TR}=4.9$; empodium $11 \mu \mathrm{m}, \mathrm{EU}=1.0$; sensillum $s$ $13 \mu \mathrm{m}$; shape and position of foretarsal sensilla same as those of preceding stages. Length of middle tarsus $23 \mu \mathrm{m}$, length of claw $9 \mu \mathrm{m}$, empodium $2 \mu \mathrm{m}$ long; hind tarsus $28 \mu \mathrm{m}$, claw $10 \mu \mathrm{m}$, empodium $7 \mu \mathrm{m}$.

Remarks. This new species differs from all its congeners by the three pairs of anterior setae on abdominal tergite VII 
Table 3. Chaetotaxy of Pseudanisentomon villaticum sp. nov.

\begin{tabular}{|c|c|c|c|c|c|c|c|}
\hline & & \multicolumn{2}{|r|}{ Larva I } & \multicolumn{2}{|r|}{ Larva II } & \multicolumn{2}{|r|}{ Imago } \\
\hline & & Formula & Primary setae & Formula & Secondary setae & Formula & $\begin{array}{c}\text { Tertiary and } \\
\text { complementary setae }\end{array}$ \\
\hline \multicolumn{8}{|l|}{ (Dorsal) } \\
\hline \multirow[t]{5}{*}{ Thorax } & I & 2 & 1 & 4 & 2 & 4 & \\
\hline & II & 4 & $\mathrm{~A} 2, \mathrm{M}$ & 6 & A4 & 6 & \\
\hline & & 12 & $\mathrm{P} 1,1 \mathrm{a}, 2,3,4,5$ & 16 & P2a, 3a & 16 & \\
\hline & III & 4 & $\mathrm{~A} 2, \mathrm{M}$ & 6 & A4 & 6 & \\
\hline & & 12 & $\mathrm{P} 1,1 \mathrm{a}, 2,3,4,5$ & 20 & P2a, 3a, 5a, 5a' & 20 & \\
\hline \multirow[t]{17}{*}{ Abdomen } & I & 0 & 0 & 4 & $\mathrm{~A} 1,2$ & 4 & \\
\hline & & 12 & $\mathrm{P} 1,1 \mathrm{a}, 2,3,3 \mathrm{a}, 3 \mathrm{a}^{\prime}$ & 12 & & 12 & \\
\hline & II & 0 & & 0 & & 10 & $\mathrm{~A} 1,2,3,4,5$ \\
\hline & & 12 & $\mathrm{P} 1,1 \mathrm{a}, 2,3,4,5$ & 16 & P2a, 4a & 16 & \\
\hline & III & 0 & & 2 & A4 & 10 & $\mathrm{~A} 1,2,3,5$ \\
\hline & & 12 & $\mathrm{P} 1,1 \mathrm{a}, 2,3,4,5$ & 16 & $\mathrm{P} 2 \mathrm{a}, 4 \mathrm{a}$ & 16 & \\
\hline & IV & 0 & & 4 & $\mathrm{~A} 4,5$ & 10 & $\mathrm{~A} 1,2,3$ \\
\hline & & 12 & $\mathrm{P} 1,1 \mathrm{a}, 2,3,4,5$ & 16 & P2a, 4a & 16 & \\
\hline & V-VI & 0 & & 4 & $\mathrm{~A} 4,5$ & 8 & $\mathrm{~A} 1,2$ \\
\hline & & 12 & $\mathrm{P} 1,1 \mathrm{a}, 2,3,4,5$ & 16 & $\mathrm{P} 2 \mathrm{a}, 4 \mathrm{a}$ & 16 & \\
\hline & VII & 0 & & 4 & $\mathrm{~A} 4,5$ & 6 & $\mathrm{~A} 2$ \\
\hline & & 12 & $\mathrm{P} 1,1 \mathrm{a}, 2,3,4,5$ & 16 & $\mathrm{P} 2 \mathrm{a}, 4 \mathrm{a}$ & 16 & \\
\hline & VIII & 6 & $\mathrm{M} 2,4,5$ & 6 & & 6 & \\
\hline & & 7 & Pc, 1a, 2, 2a & 9 & $\mathrm{P} 1 \mathrm{a}^{\prime}$ & 9 & \\
\hline & IX & & & 8 & $1,2,3,4$ & 8 & \\
\hline & $\mathrm{X}-\mathrm{XI}$ & & & & & 8 & $1,2,3,4$ \\
\hline & Telson & 9 & & 9 & & 9 & \\
\hline \multicolumn{8}{|l|}{ (Ventral) } \\
\hline \multirow[t]{4}{*}{ Thorax } & I-II & $4-2$ & $\mathrm{~A} 1,2, \mathrm{M}$ & $6-2$ & A3 & $6-2$ & \\
\hline & & 2 & $\mathrm{P} 2$ & 6 & $\mathrm{P} 1,3$ & 6 & \\
\hline & III & $4-2$ & $\mathrm{~A} 1,2, \mathrm{M} 1$ & $6-2$ & A3 & $6-4$ & M2 \\
\hline & & 2 & $\mathrm{P} 2$ & 6 & $\mathrm{P} 1,3$ & 8 & $\mathrm{P} 4$ \\
\hline \multirow[t]{12}{*}{ Abdomen } & I & 4 & $\mathrm{~A} 1,2$ & 4 & & 4 & \\
\hline & & 4 & $\mathrm{P} 1,2$ & 4 & & 4 & \\
\hline & II-III & 2 & $\mathrm{~A} 1$ & 4 & $\mathrm{~A} 2$ & 6 & A3 \\
\hline & & 4 & $\mathrm{P} 1,2$ & 4 & & 4 & \\
\hline & IV-VII & 2 & $\mathrm{~A} 1$ & 4 & $\mathrm{~A} 2$ & 6 & A3 \\
\hline & & 6 & $\mathrm{P} 1,2,3$ & 8 & $\mathrm{P} 2 \mathrm{a}$ & 10 & $\mathrm{P} 2 \mathrm{a}^{\prime}$ \\
\hline & VIII & 0 & & 0 & & 2 & A \\
\hline & & 5 & Pc, 1,2 & 7 & P1a & 7 & \\
\hline & IX & & & 4 & 1,2 & 6 & 1a \\
\hline & $\mathrm{X}$ & & & & & 6 & $1,1 \mathrm{a}, 2$ \\
\hline & XI & & & & & 8 & $1,2,3,4$ \\
\hline & Telson & 12 & & 12 & & 12 & \\
\hline
\end{tabular}

(four pairs in other species). Nakamura (2010; table 2) incorrectly described tergite VII as having three pairs of anterior setae $(A 2,4$, and 5$)$ in for $P$. donan Nakamura, 2010; however, it actually has four pairs of setae $(A 1,2,4$, and 5$)$, as shown in the following figure: Nakamura (2010: fig. 6D). Aside from this feature, this new species resembles $P$. songkiangensis by lacking foretarsal sensilla $b^{\prime} 1$ and $c^{\prime}$ and by $a$ being situated nearer to $\gamma 1$; however, it is discriminated from $P$. songkiangensis by the length of the empodium on the middle tarsus (longer in P. songkiangensis) and the lengths of foretarsal sensilla $t 3, d$, and $f 1$ (shorter in P. songkiangensis).

Distribution. Japan, known only from the Nasu Imperial Villa.
Etymology. The specific name is derived from the Nasu Imperial Villa, the type locality.

\section{Discussion}

The posterior setae $P 5$ on abdominal tergites II-III are anteriorly displaced in the larva II of $P$. villaticum sp. nov. The anterior displacement of $P 5$, however, is not observed in larva I (Fig. 8C) and adults. The same phenomenon is observed in larva II of some Eosentomon species (Nakamura 1997, 2010; Nakamura and Likhitrakarn 2009). The anterior setae $A 4$ and $A 5$ appear in larva II, but $A 5$ is not present on abdominal ter- 
gites II and III. All anterior setae occur in maturus junior. On the other hand, the same anterior displacement has been observed in adults of E. kimum Imadaté, 1964, E. nupri Nakamura, 1983, and E. rishir Nakamura, 2004, which lack $A 5$ on their abdominal tergites (Nakamura 1983, 2004). The anterior displacement of $P 5$ is probably a compensatory effect due to the absence of A5. It is likely that this is a common phenomenon in larvae II of the family Eosentomidae.

\section{Key to species of Pseudanisentomon}

1. Abdominal sternite VIII with single row of seven posterior setae ...P. dolichempodim (Yin and Zhang, 1982)

- Abdominal sternite VIII with double rows of two anterior and seven posterior setae $\ldots \ldots \ldots \ldots \ldots \ldots .2$

2. Abdominal sternites IX-X with six setae.......... 3 Abdominal sternites IX-X with four setae. . . . . . . 15

3. Abdominal tergite VII with three pairs of anterior setae $(A 2,4$, and 5$)$; foretarsal seta $x$ absent $\ldots \ldots \ldots \ldots \ldots$ Abdominal tergite VII with four pairs of anterior setae $(A 1,2,4$, and 5); foretarsal seta $x$ present. ......... 4

4. Abdominal tergites II-III with four pairs of anterior setae $(A 1,2,4$, and 5) .................... 5

- Abdominal tergites II-III with five pairs of anterior setae $(A 1,2,3,4$, and 5$) \ldots \ldots \ldots \ldots \ldots \ldots$

5. Foretarsal sensillum $b^{\prime} 1$ absent; empodia of middle and hind tarsus long ..... P. songkiangensis (Yin, 1977) Foretarsal sensillum $b^{\prime} 1$ present; empodia of middle and hind tarsus short...... P. trilinum (Zhang and Yin, 1981)

6. Abdominal tergite IV with four pairs of anterior setae $(A 1,2,4$, and 5$) \ldots \ldots \ldots \ldots \ldots \ldots \ldots \ldots \ldots$

- Abdominal tergite IV with five pairs of anterior setae $(A 1,2,3,4$, and 5$) \ldots \ldots \ldots \ldots \ldots \ldots \ldots$

7. Pseudoculus with striae and two beads; foretarsal sensillum $b^{\prime} 1$ absent ... P. sininotialis Zhang and Yin, 1984

- Pseudoculus with striae but without beads; foretarsal sensillum $b^{\prime} 1$ present ....... P. jiangxiensis Yin, 1987

8. Foretarsal sensillum $b^{\prime} 1$ absent .... P. nasuense sp. nov. Foretarsal sensillum $b^{\prime} 1$ present .............

9. Foretarsal sensillum $b^{\prime} 1$ nearer to $\delta 3^{\prime}$ than to $\delta 4^{\prime} \ldots 10$

- Foretarsal sensillum $b^{\prime} 1$ halfway between $\delta 3^{\prime}$ and $\delta 4^{\prime}$ .................................. 14

10. Labral setae absent; empodium on the middle tarsus less than $1 / 5$ of claw length ....... P. donan Nakamura, 2010

- Labral setae present; empodium on the middle tarsus longer than $1 / 3$ of claw length $\ldots \ldots \ldots \ldots \ldots \ldots 11$

11. Foretarsus less than $70 \mu \mathrm{m} \ldots \ldots \ldots \ldots \ldots \ldots 12$

- Foretarsus longer than $90 \mu \mathrm{m} . \ldots \ldots \ldots \ldots \ldots \ldots$

12. Pseudoculus without striae; foretarsal sensillum $c^{\prime}$ longer than $t 3 \ldots \ldots \ldots \ldots$. . parvum Nakamura, 2010

- Pseudoculus with striae; foretarsal sensillum $c^{\prime}$ shorter than $t 3 \ldots \ldots \ldots \ldots \ldots$. . . minystignum (Yin, 1979)

13. Pseudoculus with two or five striae; foretarsal sensillum $a$ halfway between $\gamma 1$ and $\gamma 2 \ldots \ldots$. meihwa (Yin, 1965)

- Pseudoculus with five striae and three beads; foretarsal sensillum $a$ nearer to $\gamma 1$ than to $\gamma 2 \ldots \ldots \ldots \ldots \ldots$
................... P. wanense Zhang, 1987

14. Labral setae present; empodium on the middle tarsus about $1 / 5$ of claw length ...... P. ishiii Nakamura, 1996

- Labral setae absent; empodium on the middle tarsus about $1 / 3$ of claw length ...... P. babai (Imadaté, 1964)

15. Empodia of middle and hind tarsus longer than $1 / 3$ of claw length $\ldots \ldots \ldots \ldots \ldots \ldots \ldots \ldots \ldots \ldots \ldots \ldots \ldots \ldots \ldots \ldots$

- Empodia of middle and hind tarsus less than 1/5 of

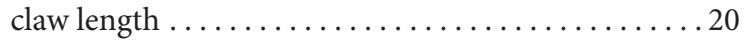

16. Foretarsal sensillum $b^{\prime} 1$ absent ............. 17

- Foretarsal sensillum $b^{\prime} 1$ present .............. 18

17. Pseudoculus simple; abdominal tergite IV with five pairs of anterior setae $(A 1,2,3,4$, and 5$) \ldots \ldots \ldots \ldots$ .P. guangxiensis (Yin and Zhang, 1982)

- Pseudoculus with three striae; abdominal tergite IV with four pairs of anterior setae $(A 1,2,4$, and 5$) \ldots \ldots$ ........... P. huichouense Zhang and Yin, 1984

18. Foretarsal sensillum $c^{\prime}$ present; abdominal tergite II with four pairs of anterior setae $(A 1,2,4$, and 5) ..... .................... sheshanensis (Yin, 1965)

- Foretarsal sensillum $c^{\prime}$ absent; abdominal tergite II with five pairs of anterior setae $(A 1,2,3,4$, and 5). . 19

19. Pseudoculus simple; foretarsal sensillum $c^{\prime}$ present.... ............... P. molykos Zhang and Yin, 1984 Pseudoculus with three striae; foretarsal sensillum $c^{\prime}$ absent ... P. cangshanense Imadaté, Yin, and Xie, 1995

20. Abdominal tergite III with five pairs of anterior setae $(A 1,2,3,4$, and 5$) \ldots \ldots \ldots \ldots \ldots \ldots \ldots \ldots \ldots \ldots \ldots \ldots$ Abdominal tergite III with four pairs of anterior setae

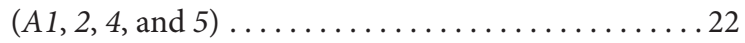

21. Pseudoculus simple; foretarsal sensillum $b^{\prime} 1$ absent ... ......... Paurophthalmum Zhang and Yin, 1984

- Pseudoculus with three long and two short striae; foretarsal sensillum $b^{\prime} 1$ present. ............. P. lishuiensis Bu, Gao, and Luan, 2020

22. Pseudoculus without inner structure; abdominal tergite II with four pairs of anterior setae $(A 1,2,4$, and 5) ... ......... Pedanempodium (Zhang and Yin, 1981)

- Pseudoculus with inner structure; abdominal tergite II with five pairs of anterior setae $(A 1,2,3,4$, and 5$) \ldots 23$

23. Pseudoculus with "\#” like striae; foretarsal sensillum $c^{\prime}$ absent ................. yongxingense Yin, 1988 Pseudoculus with a central bead; foretarsal sensillum $c^{\prime}$ present.......... P. yaoshanensis Zhang and Yin, 1984

\section{Acknowledgements}

I am indebted to His Majesty the Emperor Emeritus for providing the opportunity to conduct research and study in this area. I am grateful to the Imperial Household Agency staff for their assistance and cooperation in the survey, and to Mr. K. Furuno, Dr. K. Ishii, the late H. Sakayori, Mr. Y. Takahashi, Mr. T. Shinkawa, and Dr. Y. Minamiya for providing specimens. I would like to thank two anonymous reviewers for their constructive comments and invaluable suggestions on the manuscript, and Enago (www.enago.jp) for the English language review. 


\section{References}

Berlese, A. 1908. Nuovi Acerentomidi. Redia 5: 16-19.

Berlese, A. 1909. Monografia dei Myrientomata. Redia 6: 1-182.

Bernard, E. C. 1975. A new genus, six new species, and records of Protura from Michigan. The Great Lakes Entomologist 8: 157-181.

Bernard, E. C. 1990. New species, clarifications, and changes in status within Eosentomon Berlese (Hexapoda: Protura: Eosentomidae) from the United States. Proceedings of the Biological Society of Washington 103: 861-890.

Bu, Y., Gao, Y., and Luan, Y. 2020. Two new species of Protura (Arthropoda: Hexapoda) from Zhejiang, East China. Entomotaxonomia 42: 163-177.

Copeland, T. P. 1978. A new genus and two new species of Eosentomoidea (Protura: Eosentomidae). Proceedings of the Entomological Society of Washington 80: 473-484.

Imadaté, G. 1974. Fauna Japonica. Protura (Insecta). Keigaku Publishing Company, Ltd., Tokyo, 351 pp.

Nakamura, O. 1983. Eosentomon nupri sp. nov. from Hokkaido (Protura, Eosentomidae). Kontyû, Tokyo 51: 596-600.

Nakamura, O. 1997. Protura from Taiwan. Edaphologia 5: 17-53.

Nakamura, O. 2004. A new species of the genus Eosentomon (Insecta: Protura: Eosentomidae) from Rishiri Island, Hokkaido, Northern
Japan. Species Diversity 9: 359-366.

Nakamura, O. 2010. Taxonomic revision of the family Eosentomidae (Hexapoda: Protura) from Japan. Zootaxa 2701: 1-109.

Nakamura, O. 2019. Protura from the Chôku-tei bower in the Nasu Imperial Villa, Nasu-machi, Tochigi Prefecture, central Japan. Bulletin of Tochigi Prefectural Museum 36: 15-19. [In Japanese with English abstract]

Nakamura, O. and Likhitrakarn, N. 2009. Protura (Hexapoda) from DoiSuthep-Pui National Park, Chiang Mai, Thailand. Zootaxa 2121: 1-16.

Tipping, C. and Allen, R. T. 1994. Description of two new species of Eosentomon from Ouachita Mountains of Arkansas (Protura, Eosentomidae). Journal of the Kansas Entomological Society 67: 253-266.

Tuxen, S. L. 1964. The Protura. A Revision of the Species of the World with Keys for Determination. Hermann, Paris, 360 pp.

Tuxen, S. L. and Imadaté, G. 1975. The Protura of the Bismarck Archipelago and Solomon Islands. Bulletin of the British Museum (Natural History). Entomology 31: 331-375.

Yin, W. Y. 1999. Protura, Fauna Sinica, Arthropoda. Science Press, Beijing, China, 510 pp., 8 pls. [In Chinese with English summary]

Zhang, Z. and Yin, W. Y. 1984. A revision of the species and genera of the subfamily Anisentominae (Protura: Eosentomidae). Entomotaxonomia 6: 59-76. 